\title{
IAMJ
}

INTERNATIONAL

AYURVEDIC

MEDICAL JOURNAL

Research Article

ISSN: 2320-5091

Impact Factor: 6.719

\section{COMPARATIVE PHYSICO-CHEMICAL ANALYSIS OF SNUHI KSHARA AND APAMARGA KSHARA - AN EXPERIMENT STUDY}

\section{$\underline{\text { Rohitash Gurjar }^{1}, \text { Sanjeev Sharma }}{ }^{2}$, Narinder Singh ${ }^{3}$}

${ }^{1}$ M.S. (Ay.)-Scholar National Institute of Ayurveda Deemed to be University Jaipur, Rajasthan, India ${ }^{2}$ Guide \& Vice-Chancellor National Institute of Ayurveda Deemed To Be University Jaipur, Rajasthan, India

${ }^{3}$ Co- Guide \& Associate Professor of P.G. Dept. Of Shalya Tantra National Institute of Ayurveda Deemed to be University Jaipur, Rajasthan, India

Corresponding Author: rohitgurjar080@gmail.com

\section{https://doi.org/10.46607/iamj0209062021}

(Published Online: June 2021)

Open Access

(C) International Ayurvedic Medical Journal, India 2021

Article Received: 28/05/2021 - Peer Reviewed: 10/06/2021 - Accepted for Publication: 12/06/2021

Check for updates

\begin{abstract}
Acharya Sushruta is the pioneer of Kshara Kalpana, as he introduced Kshara Kalpana (Ayurvedic formulation) in one of the specific chapters. These alkaline preparations have many therapeutic usages and even proved to be effective in treating many disorders through external use as well as internal use. External applications of these preparations have replaced many surgical procedures. Kshara is alkaline substance obtained from the ash of herbal drugs. Kshara is a substance that has Ksharan (corrosive) nature means which removes Dusta Tvagmansadi (vitiated debris of skin, flesh etc.) or vitiated Dosha, Dhatu, Mala. Now a days Kshara and Ksharasutra is routinely prepared by Apamarga Kshara. Acharya Susruta has mentioned 23 plants from which we can make the Kshara. So, we need more plants to explore for kshara preparation. We selected Snuhi for Kshara preparation and comparative physico-chemical study is done with standard Apamarga Kshara.
\end{abstract}

Keywords: Ayurveda, Kshara, Snuhi Kshara, Physico- Chemical analysis. 


\section{INTRODUCTION}

Bhaishajya Kalpana, the science of Ayurvedic pharmaceutics primarily aims at the protection of the medicaments and preparations thereby growing their potency by showing them to different Samskara ${ }^{l}$. Conversion of the raw drug into a formulation helps in increasing the clinical efficacy as well as it renders it feasible for the administration to a patient. Kshara Kalpana is one such formulation, where the alkali present in the ash of the selected plants is extracted ${ }^{2}$. Kshara are the substances obtained from the ashes of drugs of plants (Muaaka; Raphenus sativus Linn., Snuhi; Euphorbia nerifolia Linn., Arka; Calotropis gigantea Linn. Apamarga (Achyranthes aspera Linn etc.) animals (conch shells, Cypraea moneta,coral etc.), and minerals (borax, salt petre, mixture of potassium salts etc.) origin, where alkaline portion is extracted from the ashes of these substances ${ }^{3}$. We selected two plants Apamarga and Snuhi for preparation of kshara and comparative physico-chemical analysis.

\section{Materials and Methods}

Sample were carried out following method used by Acharya Sushruta in Sushruta Samhita for preparation of Snuhi and Apamarga Ksharas ${ }^{4}$. These two samples were analyzed on these parameters like physical character, $\mathrm{PH}$, water solubility, alcohol solubility, total ash contents, moisture, water soluble ash and acid soluble ash etc.

\section{Preparation of Kshara -}

1. Collection of raw drugs- Apamarga and Snuhi Panchanga (whole plant) required for the study was collected from locally Jaipur rural area during the month of December 2020. Preparation of both Ksharas in Ksharasutra lab of PG department of
Shalya Tantra National Institute of Ayurveda deemed to be university Jaipur. Snuhi and Apamarga Panchanga were authenticated in the department of Pharmacognosy of NIA Jaipur.

2. Preparation of Snuhi And Apamarga Ash- First of all, $40 \mathrm{~kg}$ dry Snuhi whole plant and $20 \mathrm{~kg}$ dry Apamarga Panchanga was collected. After collection of plants dried Panchanga was taken in a big iron pan and burned completely. After selfcooling, of both ashes was collected separately. After completely burned we found $2.080 \mathrm{~kg} \mathrm{Apa-}$ marga ash and $4.320 \mathrm{~kg}$ Snuhi ash.

3. Preparation of Ksharajala - In classic Ayurveda, process is mention during preparation of KsharaJala the ratio of water and ash of the plant is 6:1. So $1 \mathrm{~kg}$ Snuhi ash and $1 \mathrm{~kg}$ Apamarga ash dissolved with 6 time water in an earthen pot and rubbed with hands properly for 10 minute. Then, these contents are kept as it is without any disturbance for one night. Next day, the clean supernatant liquid was decanted through the outlet of specially prepared vessel with open the tap. Then, it was filtered through eight folded cotton cloth that 1 st dissolving. The same producer repeated total 21 times. After 21-time filtrations we found clear Gomutra Varani (light Gold) Ksharajala (alkaline solution).

4. Preparation of Kshara- All the 21 times filtrates of Ksharajala were individually subjected to heat to evaporate the water content from ksharajal and to obtain Kshara, and by following this method; applied both ksharas. Prepared both Ksharas collected in airtight glass container 
Fig.1. Snuhi Panchanga (whole plant).

Fig.2. Firing Snuhi Panchanga.
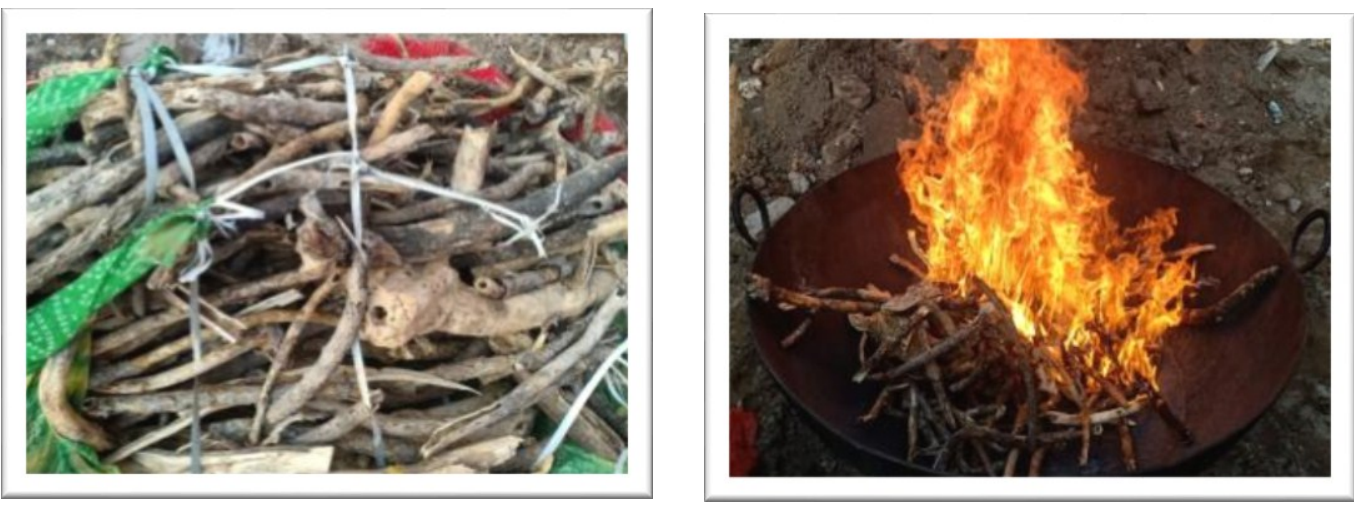

Fig.3. Ash collected

Fig. 4. Ash kept in a Stainless-Steel Vessel (6 time water)

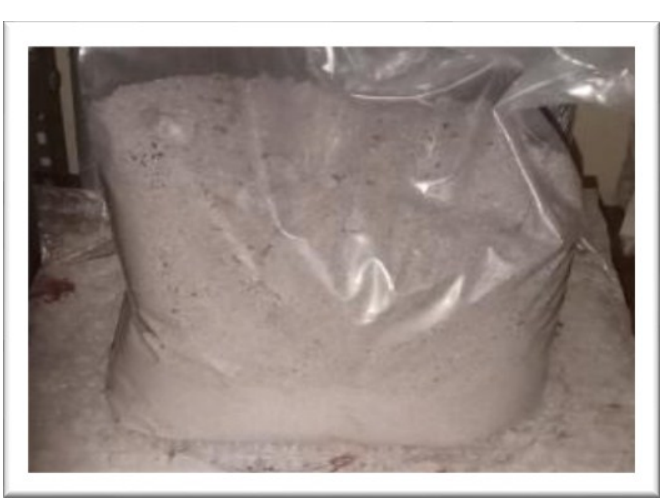

Fig.5. Filtration.

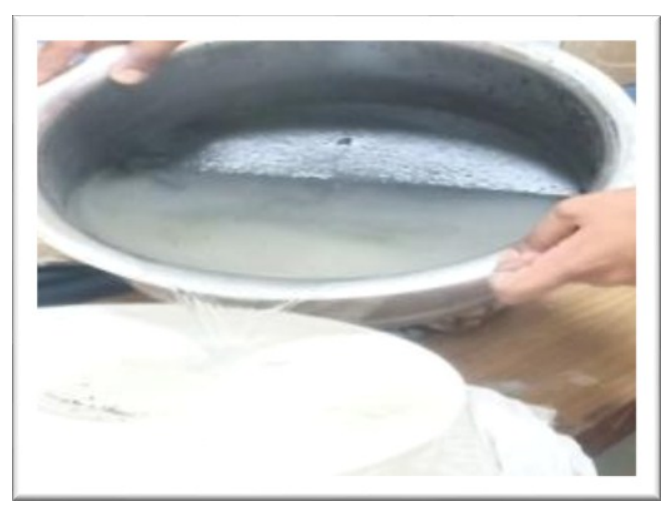

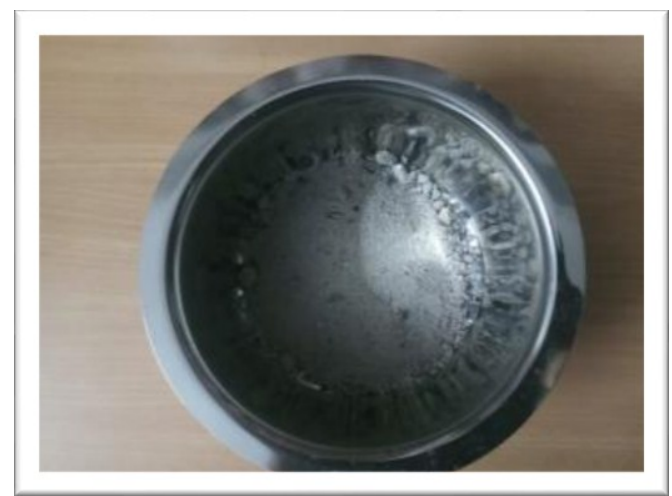

Fig.6. Boiling.

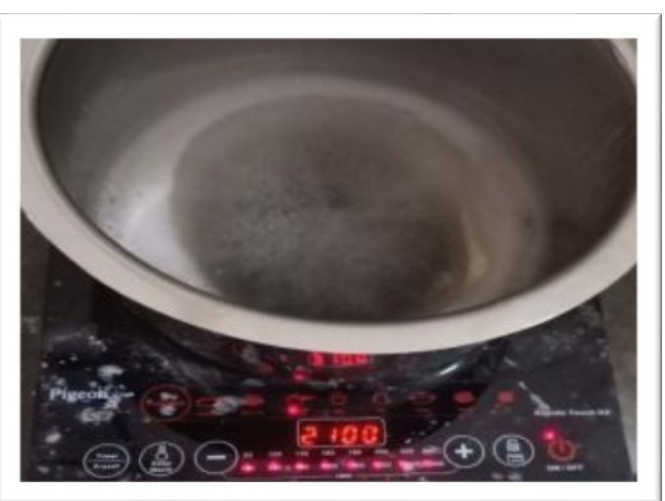


Fig.7. Prepared Snuhi Kshara

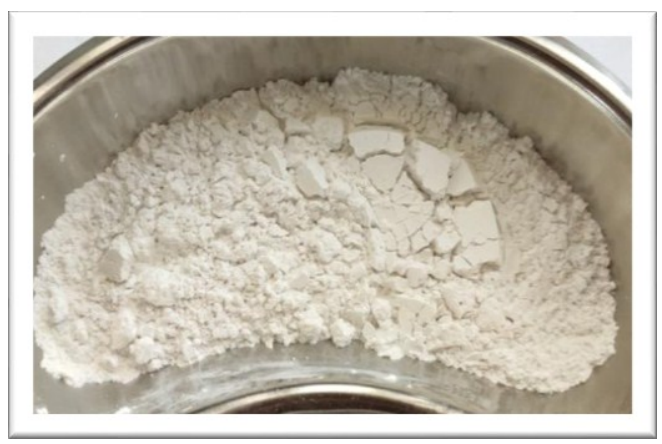

PHYSICO-CHEMICAL ANALYSIS OF BOTH PREPARED KSHARAS Physicochemical parameters macroscopic study (Color, Odor, Test) moisture content, PH, Total Ash Acid insoluble Ash water soluble Ash TLC, solubility were carried out at pharmaceutical chemistry laboratory, National Institute of Ayurveda Deemed to be University Jaipur.
Sample type - Fine powder

\section{Procedure and Observation}

1. Macroscopic study ${ }^{5}$ :

The collected sample was studied organoleptically, with naked eye \& magnifying lens, with the help of Pharmacognostical procedure i.e. Appearance, size, shape, colour, and odour and findings were recorded.

Table 1: Macroscopic study.

\begin{tabular}{|l|l|l|l|}
\hline S. No & Macroscopic study & Apamarga Kshara & Snuhi Kshara \\
\hline $\mathbf{1}$ & Color & White & White \\
\hline $\mathbf{2}$ & Odor & Odorless & Odorless \\
\hline $\mathbf{3}$ & Taste & Characteristic & Characteristic \\
\hline
\end{tabular}

2. Determination of Moisture Content/ Total Soluble Solids ${ }^{6}$ :-

Moisture content is a water holding capacity of sample, higher moisture content in sample shows that it may decrease stability.

Moisture content was determined by placing weighed sample of $5 \mathrm{gm}$ of drug in oven at $105^{\circ}$ for 5 hours, and calculated weight of sample for every 30 minute, until the weight of the sample came out to be constant, no variation of weight was recorded. This sample was allowed to cool at room temperature in a desiccator for 1 hour before weighing.

Weight of the empty petridish $=\mathrm{W}_{1} \mathrm{gm}$

Weight of the drug sample $=X$ gm

Weight of the petridish with drug before drying $\left(\mathrm{W}_{3}\right)$ $=\left(\mathrm{W}_{1}+\mathrm{X}\right)$

Weight of petridish after drying $=\mathrm{W}_{2} \mathrm{gm}$

Loss on drying in $\%=\mathrm{W}_{3}-\mathrm{W}_{2} \times 100 / \mathrm{X}$

Table 2: Moisture Content

\begin{tabular}{|l|l|l|l|l|l|l|}
\hline $\begin{array}{l}\text { S. } \\
\text { No }\end{array}$ & Sample & $\begin{array}{l}\text { Weight } \\
\text { sample }\end{array}$ & $\begin{array}{l}\text { Weight of con- } \\
\text { tainer }\end{array}$ & $\begin{array}{l}\text { Weight after drying with } \\
\text { container }\end{array}$ & $\begin{array}{l}\text { Weight after drying with- } \\
\text { out container }\end{array}$ & $\begin{array}{l}\text { Value } \\
\%\end{array}$ \\
\hline 1 & $\begin{array}{l}\text { Apamarga } \\
\text { kshara }\end{array}$ & $5.1502 \mathrm{gm}$ & $31.5530 \mathrm{gm}$ & $36.3710 \mathrm{gm}$ & $0.5132 \mathrm{gm}$ & $9.96 \%$ \\
\hline 2. & Snuhi kshara & $5.0392 \mathrm{gm}$ & $41.5530 \mathrm{gm}$ & $46.1627 \mathrm{gm}$ & $0.4295 \mathrm{gm}$ & $8.52 \%$ \\
\hline
\end{tabular}


3. Determination of $\mathbf{p H}^{\mathbf{7}}$ : The $\mathrm{pH}$ value of an aqueous liquid may be defined as the common reciprocal of the hydrogen ion concentration expressed in gram per litre. It practically means the quantitative indication of the acidity or basic nature of a solution.

- The $\mathrm{pH}$ of a given solution is measured by using digital $\mathrm{pH}$ meter.

- First Standardized the $\mathrm{pH}$ meter. Tablets of different $\mathrm{pH}$ were taken, and each tablet was dissolved in $100 \mathrm{ml}$ of distilled water to prepare solutions of different $\mathrm{pH}$.
- The instrument was switched on and left for some time until required different $\mathrm{pH}$ solutions appeared.

- Buffer solution was taken in the beaker and the electrode was dipped in it. Same procedure was repeated for the other buffer solution after washing the electrode thoroughly with distilled water.

- The sample was taken (10\% aqueous solution) and electrode was dipped in it and the value of $\mathrm{pH}$ was noted.

Table 3: Determination of $\mathrm{pH}$

\begin{tabular}{|l|l|l|}
\hline S. No & Sample & pH \\
\hline $\mathbf{1}$ & Apamarga Kshara & 10.4 \\
\hline $\mathbf{2}$ & Snuhi Kshara & 10.3 \\
\hline
\end{tabular}

4. Determination of Total $\mathbf{A s h}^{8}$ :- Ash is a quantity analysis technique for determining siliceous material and inorganic substance in sample. Acid Insoluble Ash shows siliceous material and heavy metals. Water Soluble Ash shows quantity of water inorganic Substance. The total ash method is designed to measure the total amount of material remaining after ignition. This includes both physiological ash which is derived from the plant tissue itself and non-physiological ash which is the residue of the extraneous matter (e.g. sand and soil) adhering to plant surface. Silica Crucible was cleaned, dried well, labelled with glass pencils and then weighed to constant weight. 5 grams of powdered drug sample was put in the Silica crucible. The drug was spread evenly into a thin layer. This crucible was placed in a muffle furnace and ignited at a temperature of $450^{\circ} \mathrm{C}$ for about 6 hours or more until the ash was totally free from Carbon. The crucible containing the ash was allowed to be cooled in desiccators and subsequently weighed to constant weight. The percentage of ash with reference to the air-dried drug was calculated.

\section{Calculation:}

Wt. of Empty Silica Crucible $=\mathrm{A}_{1}$ gm

Wt. of Sample $(\mathrm{X})=\mathrm{X}$ gm

Wt. of the Crucible with Ash $=\mathrm{A}_{2}$ gm

Percentage of Total Ash $=\left[\mathrm{A}_{2}-\mathrm{A}_{1} / \mathrm{X}\right] \mathrm{x} 100$

Table 4: Total Ash content.

\begin{tabular}{|l|l|l|l|l|l|}
\hline S. No & Sample & $\mathbf{A}_{\mathbf{1}}$ & $\mathbf{X}$ & $\mathbf{A}_{\mathbf{2}}$ & Total Ash (\%) \\
\hline $\mathbf{1}$ & Apamarga Kshara & $30.2862 \mathrm{gm}$ & $4.9791 \mathrm{gm}$ & $34.8014 \mathrm{gm}$ & $90.68 \%$ \\
\hline $\mathbf{2}$ & Snuhi Kshara & $39.7964 \mathrm{gm}$ & $5.0163 \mathrm{gm}$ & $44.4915 \mathrm{gm}$ & $93.59 \%$ \\
\hline
\end{tabular}

5. Solubility9:- Solubility is defined as the amount of substance that passes into solution to achieve a saturated solution at constant temperature and pressure. Solubility are expressed in terms of maximum volume or mass of the solute that dis- solve in a given volume or mass of a solvent. Pharmacopoeias give solubility's in terms of the number of parts by volume of solvent required to dissolve one part by weight of a solid, or one part by volume of a liquid. 
Table 5: Solubility

\begin{tabular}{|l|l|}
\hline Descriptive term $\mathbf{( g m )}$ & Approximate volume of solvent in milliliters per gram of solute (ml) \\
\hline Very soluble & less than 1 \\
\hline Freely soluble & from 1 to 10 \\
\hline Soluble & from 10 to 30 \\
\hline Sparingly soluble & from 30 to 100 \\
\hline Slightly soluble & from 100 to 1000 \\
\hline Very slightly soluble & from 1000 to 10,000 \\
\hline Insoluble or practically insoluble & more than 10,000 \\
\hline
\end{tabular}

\begin{tabular}{|l|l|l|l|}
\hline S. No & Sample & Descriptive term & Approximate volume (ml) \\
\hline $\mathbf{1}$ & Apamarga Kshara & Soluble & 10 To30 \\
\hline $\mathbf{2}$ & Snuhi Kshara & Soluble & 10 To 30 \\
\hline
\end{tabular}

6. Determination of Acid Insoluble Ash ${ }^{\mathbf{1 0}}$ :- Acid insoluble Ash value determined as per Pharmacopoeia of India, 1996. Boiled the total ash with $25 \mathrm{ml}$ of $2 \mathrm{M}$ hydrochloric acid for 5 minutes, collected the insoluble matter in a Gooch crucible or on an ash less filter paper, washed with hot water, ignite, cool in a desiccator and weighed. Calculate the percentage of acid insoluble ash with reference to the air - dried drug.

\section{Calculation:-}

Wt. of drug sample - X gm

Wt. of Crucible $=\mathrm{G} 1 \mathrm{gm}$

Wt. of Crucible with insoluble Ash $=\mathrm{G} 2 \mathrm{gm}$

Wt. of insoluble ash $(\mathrm{G} 3)=\mathrm{G} 2-\mathrm{G} 1$

Percentage of acid insoluble ash $=\mathrm{G} 3 / \mathrm{X} \times 100$

Table 6: Acid Insoluble Ash

\begin{tabular}{|l|l|l|l|l|l|l|}
\hline S. No & Sample & X & G1 & G2 & G3 & Acid insoluble ash \% \\
\hline $\mathbf{1}$ & Apamarga Kshara & $5.0398 \mathrm{gm}$ & $32.8033 \mathrm{gm}$ & $32.9079 \mathrm{gm}$ & $0.1046 \mathrm{gm}$ & 2.07 \\
\hline $\mathbf{2}$ & Snuhi Kshara & $5.1151 \mathrm{gm}$ & $33.1624 \mathrm{gm}$ & $33.2738 \mathrm{gm}$ & $0.1114 \mathrm{gm}$ & 2.17 \\
\hline
\end{tabular}

\section{Determination of Water-soluble Ash ${ }^{11}$ :- Water -} soluble ash value determined as per Pharmacopoeia of India 1996. Boiled the total ash for 5 minutes with 25 $\mathrm{ml}$ of water; collected the insoluble matter in a Gooch's Crucible or on an ash less filter paper, Washed with hot water and ignite for 15 minutes at a temperature not exceeding $450 \mathrm{C}$. Subtract the weight of the insoluble matter from the weight of the ash; the difference in weight represented the water - soluble ash. Calculate the percentage of water - soluble ash with reference to the air - dried drug.

\section{Calculation: -}

Wt. of drug sample - X gm

Wt. of total ash - A gm

Wt of Crucible - G1 gm

Wt. of Crucible with insoluble Ash - G2 gm

Wt. of insoluble ash (G3) $=\mathrm{G} 2-\mathrm{G} 1$

Water soluble ash $(\mathrm{G} 4)=\mathrm{Wt}$. of total ash Agm- Wt. of insoluble(G3)

Percentage of water-soluble ash $=\mathrm{A}-[(\mathrm{G} 3) / \mathrm{X}] \times 100$

Table 7: Water-soluble Ash:

\begin{tabular}{|l|l|l|l|l|l|l|l|l|}
\hline S. N & Sample & X & A & G1 & G2 & G3 & G4 & Water soluble ash \% \\
\hline 1 & Apamarg Kshara & $4.9791 \mathrm{gm}$ & 90.68 & $30.2862 \mathrm{gm}$ & $30.5946 \mathrm{gm}$ & $0.3084 \mathrm{gm}$ & $4.2068 \mathrm{gm}$ & 84.49 \\
\hline 2 & Snuhi Kshara & $5.0163 \mathrm{gm}$ & 93.59 & $39.7964 \mathrm{gm}$ & $41.0038 \mathrm{gm}$ & $1.2074 \mathrm{gm}$ & $3.4877 \mathrm{gm}$ & 69.53 \\
\hline
\end{tabular}




\section{DISCUSSION}

The physico-chemical analysis of the two samples were conducted at pharmaceutical chemistry laboratory, National Institute of Ayurveda Deemed to be University Jaipur.

Macroscopic study like colour, odour, and taste were recorded along with the evaluation of the parameters like loss on drying, total ash, water soluble ash, acid insoluble ash, $\mathrm{pH}$, water soluble extractive value and alcohol soluble extractive value by following standard procedures $^{12}$.

The quantity of AK (Apamarga Kshara) and SK (Snuhi Kshara) samples obtained were $240 \mathrm{~g}$ and $160 \mathrm{~g}$ respectively. The less quantity of SK sample suggests that the west solids contents present more in Snuhi Panchanga. The colour of both samples were whitish. The taste of both samples was Characteristic. The Characteristic taste suggests the presence of alkali contents. Both samples were odorless. The macroscopic characters of the two samples are shown in Table 1.

Loss on drying is an important parameter to be measured for the Kshara. As it's hygroscopic in nature due the presence of alkaline composites and hence the loss on drying values means the limit to which the sample has absorbed moisture. The lesser the value of loss on drying the stable the Kshara is measured. The values of loss on drying for AK and SK samples were found to be $9.92 \%$ and $8.52 \%$ separately. These values suggest that SK sample is less hygroscopic and hence more stable. Table no 2 shown moisture contents.

$\mathrm{PH}$ shows the relative acidity or alkalify of any sample. The $\mathrm{pH}$ for AK and SK samples were found to be 10.4 and 10.3 which clearly suggests about the alkaline nature of the Kshara. Table no. 3 shown PH Value of both samples.

The total ash values denoted the amount of inorganic material existing in the given sample. For example, Kshara is obtained after complete burning of the organic matter of the drug and hence ash values should be higher. Total ash values for AK and SK were found to be $90.68 \%$ and $93.59 \%$ separately. The lower value in AK samples denotes that some amount of organic matter was also present in the sample. table no.4 shown total ash value of both samples.

The alcohol solubility extractive value for AK and SK were 10 to 30 and 10 to 30 separately. The result obtained from the test depict that both the samples had no elements which are insoluble in the alcohol or water. Table no 5 shown solubility of both sample in the water and alcohol.

The values obtained for acid insoluble ash for $\mathrm{AK}$ and SK were $2.07 \%$ and $2.17 \%$ separately. Acid insoluble ash indicates about the ash obtained from the matter which are not soluble in water for example silica. This value should be less for a standard product. The values obtained for the two samples indicate the quality of the two samples. Table no. 6 and 7 shown acid insoluble ash contents.

The water-soluble ash for AK and SK were 84.49\% and $69.53 \%$ separately Water-soluble extractive value for both the samples was found to be $100 \%$. The results obtained from the test depicts that both the samples consisted of the elements which are completely soluble in water. This is in perfect compliance with the classics where it is been told that Kshara is extracted from the ash of the plant after saturated it in water. So, the $100 \%$ value of water-soluble extractives is justified.

The result of physico-chemical analysis study has advocated both samples with standard parameters. the present study it could be concluded that pharmaceutical processing imparts specific qualities to a formulation which helps in the protection of the clinical efficacy. Snuhi Kshara sample can be considered to be an alternative of Apamraga Kshara. which may also have therapeutic activity of their own.

\section{CONCLUSION}

Now a days Kshara and Ksharasutra is routinely prepared by Apamarga Kshara. It is known as standard Apamarga Kshara and Ksharasutra and is known device for the treatment of Fistula-in-ano, Arsha, Arbuda, Nadivrana etc. But we cannot depend always on single type of Kshara and Ksharasutra. There is a need to explore other drugs which can be used in the preparation of kshara and Ksharasutra in accordance 
with the references made by our Acharyas at different places in their treatises. This Physico-chemical analysis study proves that Snuhi Kshara can be best alternative of Apamarga Kshara. A clinical study may further clarify comparative clinical efficacy of the two samples of Kshara.

\section{REFERENCES}

1. Vaidya Jadavji Trikamji Acharya, editor, (1st ed). Charaka Samhita of Acharya Agnivesha, Sootra Sthana, Rasavimaniya, Chapter 1, Verse 21(2). Varanasi: Chaukhambha Orientalia, 2007; p.235

2. The Ayurvedic Formulary of India. Part I, 2nd Ed. New Delhi: Government of India, Ministry of Health and Family Welfare, 2003; p.163.

3. Vaidya Yadavji Trikamji Acharya, Narayanaram Acharya, editors, (1st ed). Sushrutha Samhita of Acharya Sushrutha, Sootra Sthana, Ksharapakavidhi Adhyaya, Chapter 11, Verse 11-13. Varanasi: Chaukhambha Surabharti Prakasan, 2014; p.46-4

4. Vaidya Yadavji Trikamji Acharya, Narayanaram Acharya, editors, (1st ed). Sushrutha Samhita of Acharya Sushrutha, Sootra Sthana, Ksharapakavidhi Adhyaya, Chapter 11, Verse 11-13. Varanasi: Chaukhambha Surabharti Prakasan, 2014; p.46-4

5. Dr. K. R. khandelwal. Practicalpharmacognosy, $20^{\text {th }}$ edition, p. 3-5.

6. Laboratory guide for the analysis of Ayurveda and siddha formulations, CCRAS, Dept. Of Ayush, ministry of health and family welfare, govt. of India New Delhi, P. 27.

7. CCRAS, Laboratory guide for analysis of Ayurveda \& siddha formulations, $\mathrm{p}-29,30$

8. Laboratory guide for the analysis of Ayurveda and siddha formulations, CCRAS, Dept. Of Ayush, ministry of health and family welfare, govt. of India New Delhi, P. 83-87.

9. Laboratory guide for the analysis of Ayurveda and siddha formulations, CCRAS, Dept. Of Ayush, ministry of health and family welfare, govt. of India New Delhi, P. 89-92.

10. Dr. D.R. LOHAR, Protocol For Testing Ayurvedic, Siddha \&Unani Medicines, Government of India, Department of AYUSH, Ministry of Health \& Family Welfare, Pharmacopoeial Laboratory For Indian Medicines, Ghaziabad, P- 123-124.

11. Lavekar G. S. et al, Laboratory guide for the Analysis of Ayurveda and Siddha formulations, Central Council for Research in Ayurveda and Siddha, Department of Ayush, Ministry of Health and Family Welfare, Government of India, New Delhi, P 35.

12. Lohar DR. Protocol For Testing, 1st Ed. Ghaziabad: Pharmacopeial Laboratory For Indian Medicines, Government Of India, Ministry of Health and Family Welfare, p.49-50,112

\section{Source of Support: Nil Conflict of Interest: None Declared}

How to cite this URL: Rohitash Gurjar et al: Comparative Physico-Chemical Analysis Of Snuhi Kshara And Apa-Marga Kshara - An Experiment Study. International Ayurvedic Medical Journal \{online\} 2021 \{cited June, 2021\} Available from:

http://www.iamj.in/posts/images/upload/1167 1174.pdf 